\title{
Multiparticulate oral formulations as a viable strategy for precise drug dosing in pediatrics: propranolol case study
}

\author{
Ivana Kurćubić ${ }^{1 *}$, Sandra Cvijićc ${ }^{1}$, Milica Lukić \\ Svetlana Ibrić ${ }^{1}$, Jelena Djuriš ${ }^{1}$
}

${ }^{1}$ University of Belgrade - Faculty of Pharmacy, Department of Pharmaceutical Technology and Cosmetology, Vojvode Stepe 450, 11221 Belgrade, Serbia

${ }^{2}$ Pharmacy "Dr.Max", Miloša Pocerca 25, 11000, Belgrade, Serbia

*Corresponding author: Ivana Kurćubić, E-mail: ivana.kurcubic@pharmacy.bg.ac.rs

\begin{abstract}
The development of solid dosage forms that are both convenient for administration and allow precise drug dosing for pediatric patients is one of the great challenges in contemporary pharmaceutical technology. The presented study has utilized propranolol hydrochloride, as one of the most frequently prescribed drugs that require manipulation of the conventional dosage forms to be administered to children. Multiparticulate oral formulations, powder- and granulefilled capsules, as well as mini tablets, were prepared and characterized in terms of their mass and content uniformity and compared to conventional marketed tablets split into halves and quarters. The obtained results have demonstrated the superiority of the multiparticulate formulations, in terms of their average mass and drug content uniformity. It has also been demonstrated that, due to improved flowability, granule-filled capsules are more conveniently compounded and provide higher content uniformity compared to powder-filled capsules. The presented compounding method could be easily employed in community pharmacy settings. Mini tablets with high and uniform content of propranolol hydrochloride have been successfully prepared, thereby presenting a viable strategy for efficient drug dose adjustment.
\end{abstract}

Keywords: propranolol, pediatric dosage forms, multiparticulates, mini tablets, uniformity of content

doi.org/10.5937/arhfarm71-30717 


\section{Introduction}

The development of solid oral dosage forms that are convenient for administration to pediatric patients is one of the current challenges, both from the perspective of pharmaceutical technology and pharmacotherapy. Compared to liquid products, which are predominantly formulated dosage forms for children, solid dosage forms may provide better stability, dosing accuracy, flexibility in administration, potential for modified drug release, affordable production, etc. (1-4). The development of pediatric solid dosage forms is recommended by the official guidelines as well $(5,6)$. Solid oral dosage forms can be developed in a manner that allows ease of administration, favorable organoleptic properties, and accurate dosing with relatively simple formulations containing safe excipients in minimal amounts (7).

There is a great therapeutical need for the development of cardiovascular medicines in dosage forms suitable for administration to children. A survey (8) reported that antiarrhythmics and antihypertensives (renin-angiotensin inhibitors and beta-blockers) are among the medicines most frequently used off-label or without a marketing authorization in pediatric patients. Propranolol hydrochloride, hereinafter referred to as PROP, is a non-selective beta-blocker used in the control of arrhythmia, hypertension, and pheochromocytoma in the pediatric population, usually at a dose of $0.25-0.5 \mathrm{mg} / \mathrm{kg}$ 3-4 times daily, adjusted according to the clinical response. It is also used in migraine prophylaxis at a dose of $20 \mathrm{mg}$ 2-3 times daily for children at the age of 12, and in doses of 80-160 mg daily (corresponding to the adult doses) for children over the age of 12 . Moreover, PROP dose of $1 \mathrm{mg} / \mathrm{kg}$ 3-4 times daily is used for the treatment of congenital heart defect that involves four anatomical abnormalities referred to as Fallot's tetralogy (9).

Due to their wide therapeutic application, several PROP products are currently available on the European market (Table I) $(9,10)$ in different dosage forms: sustained release capsules, (un)coated tablets and oral solutions. As listed in the Summary of Products' characteristics (SmPC) (Table I) tablets and oral solutions can be administered to pediatric patients. However, PROP oral solutions are not available on the Serbian market. Furthermore, conventional solid oral dosage forms, such as tablets and capsules, may not be convenient for administration to children, due to inability or difficulties in swallowing (10). It is believed that children can safely swallow tablets and capsules from the age of six, but this is highly dependent on individual compliance and training, as well as on dosage form properties (size, shape and weight). There are no specific instructions in SmPCs regarding the administration of the marketed PROP products (Table I) to pediatric patients, especially in terms of adjustment of the required dose according to body weight.

In order to adjust the pediatric dose and facilitate the administration of the medicine to a child, tablets can be manipulated in various ways. The most common practice includes splitting or crushing of tablets, which may lead to inaccurate dosing (12-15), and 
concomitant side effects or changes in therapeutic effect (3). Another alternative is extemporaneous compounding of unit dose powders from commercially available tablets.

Table I Propranolol products for oral administration marketed in Europe (9-11)

Tabela I Preparati propranolola za oralnu primenu koji su registrovani u Evropi (9-11)

\begin{tabular}{|c|c|}
\hline $\begin{array}{l}\text { Trade name, dosage(s) and } \\
\text { manufacturer }\end{array}$ & $\begin{array}{c}\text { Dosage form and remarks from SmPCs relevant } \\
\text { for administration of products to paediatric } \\
\text { patients }\end{array}$ \\
\hline $\begin{array}{l}\text { Bedranol }{ }^{\circledR} 80 \text { and } 160 \mathrm{mg}, \\
\text { Sandoz Ltd }\end{array}$ & sustained release capsules \\
\hline $\begin{array}{l}\text { Beta-Prograne }{ }^{\circledR} 160 \mathrm{mg} \\
\text { Half Beta-Prograne }{ }^{\circledR} 80 \mathrm{mg} \\
\text { Tillomed Laboratories Ltd }\end{array}$ & $\begin{array}{l}\text { (not suitable for use in children, } \\
\text { according to SmPCs) }\end{array}$ \\
\hline $\begin{array}{c}\text { Propranolol }{ }^{\circledR}, \\
\text { 10, } 40 \text { and } 80 \mathrm{mg}, \\
\text { Accord Healthcare Ltd }\end{array}$ & $\begin{array}{c}\text { film-coated tablets } \\
\text { (the score line is present but only to facilitate } \\
\text { breaking for ease of swallowing and not to divide } \\
\text { into equal doses) }\end{array}$ \\
\hline $\begin{array}{c}\text { Propranolol } \\
10 \text { and } 40 \mathrm{mg}, \\
\text { Aurobindo Pharma, Milpharm Ltd }\end{array}$ & $\begin{array}{c}\text { film-coated tablets } \\
\text { (can be divided into equal doses) }\end{array}$ \\
\hline $\begin{array}{l}\text { Propranolol } \mathrm{BP}^{\circledR}, \\
\text { 10, } 40,80 \text { and } 160 \mathrm{mg}, \\
\text { Accord-UK Ltd }\end{array}$ & $\begin{array}{l}\text { film-coated tablets } \\
\text { (division line is present but the manufacturer does } \\
\text { not specify whether it allows easier swallowing } \\
\text { and/or division into equal doses) }\end{array}$ \\
\hline $\begin{array}{l}\text { Propranolol hydrochloride }{ }^{\circledR} \\
5 \mathrm{mg} / 5 \mathrm{ml}, 10 \mathrm{mg} / 5 \mathrm{ml}, 40 \mathrm{mg} / 5 \mathrm{ml}, \\
50 \mathrm{mg} / 5 \mathrm{ml} \\
\text { Thame Laboratories }\end{array}$ & $\begin{array}{l}\text { oral solution } \\
\text { (administered with graduated oral syringe or } \\
\text { graduated cup; additional bottle adaptor) }\end{array}$ \\
\hline $\begin{array}{l}\text { Propranolol Rosemont }^{\circledR} \\
5 \mathrm{mg} / 5 \mathrm{ml}, 10 \mathrm{mg} / 5 \mathrm{ml}, 40 \mathrm{mg} / 5 \mathrm{ml} \text {, } \\
50 \mathrm{mg} / 5 \mathrm{ml} \\
\text { Rosemont Pharmaceuticals Ltd }\end{array}$ & oral solution \\
\hline $\begin{array}{l}\text { Hemangiol }^{\circledR} 3.75 \mathrm{mg} / \mathrm{ml} \\
\text { Pierre Fabre Dermatologie }\end{array}$ & $\begin{array}{c}\text { oral solution } \\
\text { (administered with graduated oral syringe) }\end{array}$ \\
\hline $\begin{array}{l}\text { Propranolol }{ }^{\circledR} 40 \mathrm{mg}, \\
\text { Galenika } \mathrm{AD}^{*}\end{array}$ & $\begin{array}{c}\text { uncoated tablets } \\
\text { (can be divided in four equal doses) }\end{array}$ \\
\hline
\end{tabular}

* The only propranolol product marketed in Serbia 
Multiparticulate systems, such as powders, granules, microparticles, pellets or mini tablets, provide the means for subdivision of the dose, as well as easier administration compared to the monolithic dosage forms (e.g. tablet). Due to their flexible nature, multiparticulate systems are expected to have wide applicability in the development of pediatric medicines (16). Multiparticulates can be packed in suitable, multidose containers (such as wide-mouthed glass jar), but in order to increase the dosing precision, it is more convenient to prepare single-dose preparations. For this purpose, subunits can be compressed into small tablets or packed into powder papers, sachets or hard capsules (17). In the latter case, hard capsules serve as a container i.e., they are not meant for swallowing in whole. Infants at the age of 6 months and toddlers can physiologically and anatomically swallow multiparticulates mixed with soft food or beverages, depending on the size, shape and hardness of the particles $(7,18)$. Mini tablets (tablets with a diameter of up to $4 \mathrm{~mm}$ ) have been proposed as a new modality of drug delivery for children at the age of 2 - 6 years (19). Mini tablets can be supplied in the form of paper or hard capsules, or they can be administered using a suitable dosing device or electronic dispenser if packed in multidose containers $(7,18,20)$. Different options to administer multiparticulates to pediatric patients are depicted in Figure 1.

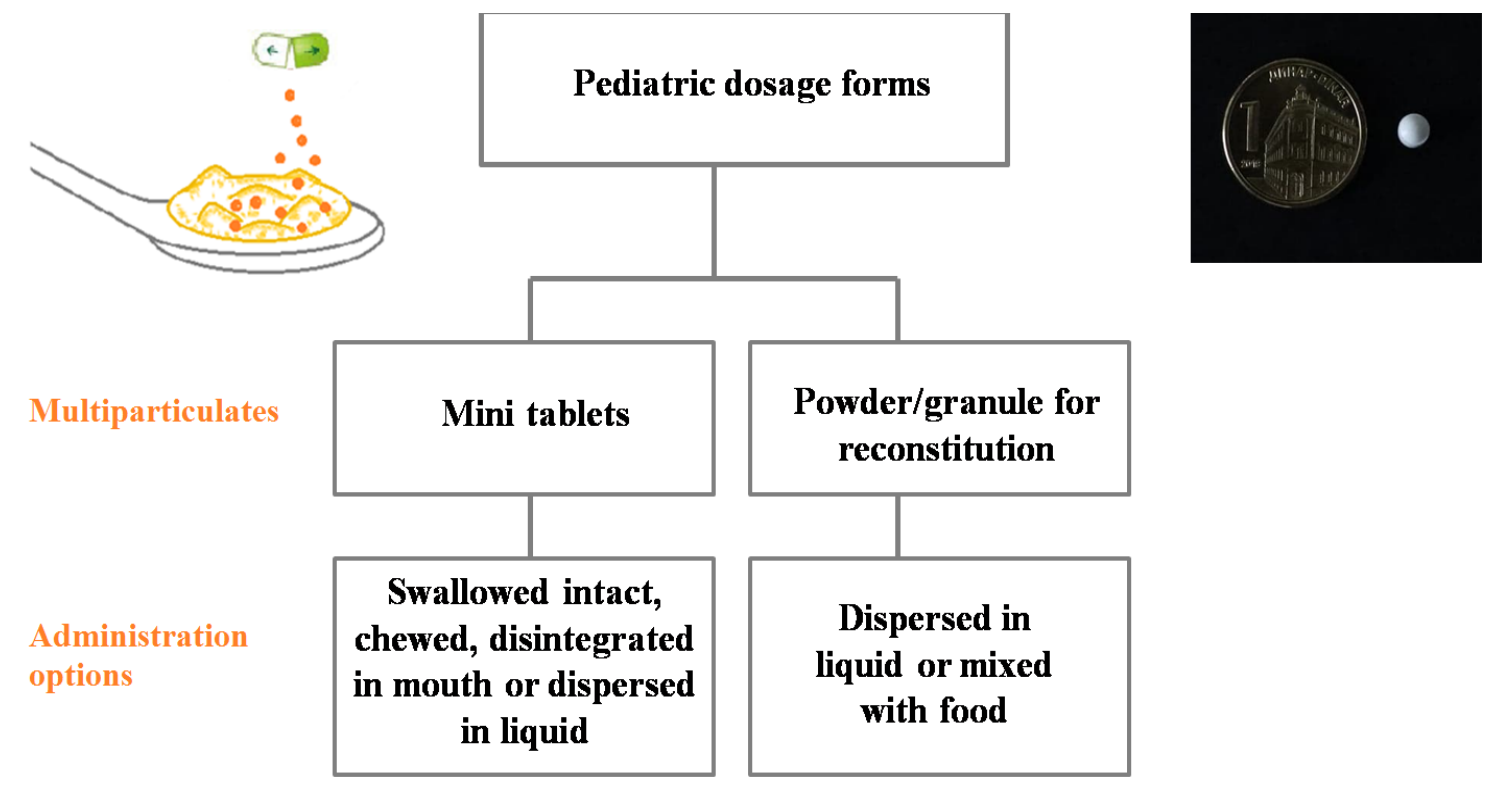

Figure 1. Administration methods for mini tablets and powder/granules within pediatric dosage forms

Slika 1. Načini primene mini tableta i praškova/granula u sastavu farmaceutskih oblika za pedijatrijsku populaciju

The administration of multiparticulates with soft, semi-solid foods has been recommended for infants from the age of 6 months (5); however, in this case, particle size and potential impact of food on drug absorption need to be carefully considered (21). 
Mini tablets with sodium valproate (22), levetiracetam (23) and the enzymes amylase, lipase and protease (24) are available in the European Union (EU). Mini tablets with $150 \mathrm{mg}$ of sodium valproate are intended for children from 6 months to 3 years, whereas mini tablets with $300 \mathrm{mg}$ of sodium valproate are used in children over the age of 3 . Unfortunately, none of these products is marketed in Serbia.

The aim of this study was to assess the potential for the dose adjustment of PROP to the pediatric patients by using commercially available tablets and extemporaneously compounded multiparticulate oral formulations: powder-filled hard capsules, granulefilled hard capsules, and mini tablets.

\section{Experimental part}

\section{Materials}

Commercially available PROP tablets (Propranolol ${ }^{\circledR} 40 \mathrm{mg}$, Galenika AD, Serbia) were used to assess the accuracy of various tablet splitting techniques. In addition, commercially available tablets were used as a source of PROP, and together with directly compressible mannitol (Parteck ${ }^{\circledR}$ M 200, Merck, Germany), as a filler and sweetening agent, were used to extemporaneously compound powder-filled capsules. PROP, Parteck $^{\circledR}$ M 200 and 5\% aqueous solution of polyvinylpyrrolidone (PVP 40, Sigma Aldrich, Germany) were used to prepare granule-filled capsules. Mini tablets were prepared using PROP, Parteck ${ }^{\circledR}$ M 200 and magnesium stearate (Sigma-Aldrich, Germany) as a lubricant. The theoretical content of PROP in the prepared formulations (powder-filled capsules, granule-filled capsules and mini tablets) was $3 \mathrm{mg}$ or $6 \mathrm{mg}$. Dilute hydrochloric acid (1\% V/V; Sigma-Aldrich, Germany) and methanol (Merck, Germany), used as reagents, were of Ph. Eur. 10.0 quality.

\section{Methods}

1. Subdivision of scored tablets

Propranolol $^{\circledR} 40 \mathrm{mg}$ scored tablets (Galenika AD, Serbia) were tested in terms of uniformity of mass of the subdivided parts, according to the procedure described in $\mathrm{Ph}$. Eur. 10.0. Tablets (0478). In brief, 30 tablets were broken into halves or quarters, and one part (half or quarter) from each tablet was taken for the test. Each part was weighted individually, and the average mass and standard deviation (SD) were calculated. The tablets complied with the test if no more than one individual mass was outside the limits of $85-115 \%$ of the average mass. In contrast, the tablets failed to comply with the test if more than one individual mass was outside these limits or if one individual mass was outside the limits of $75-125 \%$ of the average mass.

Since there is no standard procedure for tablet subdivision, we have tested five different splitting techniques: four techniques by hand (12) and using a commercially available tablet-splitter, as illustrated in Figure 2. 


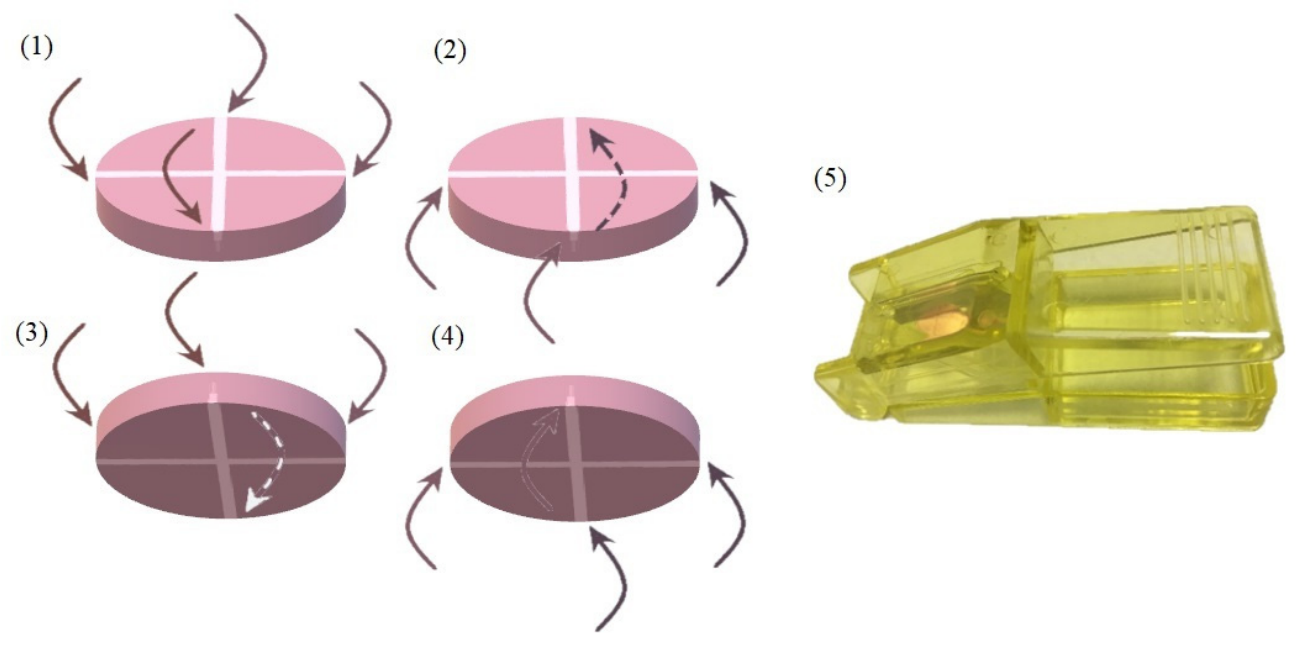

Figure 2. The applied tablet splitting techniques: by hand 1-4, and using the tabletsplitter 5; arrows represent the direction of the force applied during tablet splitting

Slika 2. Primenjene tehnike deljenja tableta: ručno 1-4 i pomoću "sekača za tablete" 5; strelice predstavljaju smer vršenja pritiska prilikom deljenja tableta

\section{Preparation of powder- and granule-filled capsules}

Powder-filled hard capsules size 3 (capsule volume $0.3 \mathrm{ml}$ ) were prepared using semi-automatic capsules filling machine (Otima Aluminium ${ }^{\circledR}$, Farmalabor, Italy), to comply with the procedure commonly used in local pharmacies. In order to prepare 40 capsules needed for the study, each containing either $3 \mathrm{mg}$ or $6 \mathrm{mg}$ PROP, the number of required tablets was calculated (equal to 3 and 6 tablets, respectively). The tablets were pulverized in a mortar with a pestle, sieved through $180 \mu \mathrm{m}$ mesh sieve, and then the powder was transferred to a graduated cylinder, followed by the subsequent addition of a filler (Parteck ${ }^{\circledR}$ M 200) to the required volume $(12 \mathrm{ml})$. The powder from the graduated cylinder was transferred to a mortar, mixed well with a pestle, and used to fill hard capsules (kindly provided by Farmalabor, Serbia).

Granule-filled hard capsules size 3 were prepared using PROP, Parteck ${ }^{\circledR}$ M 200 and $5 \%$ PVP solution. Firstly, sufficient amounts of PROP obtained from the pulverized tablets and Parteck ${ }^{\circledR}$ M 200 were mixed in a mortar with pestle, followed by the gradual addition of the PVP solution (in a dropwise manner) until the required moisture content was achieved (inspected manually). The wet powder mixture was then sieved through a $0.8 \mathrm{~mm}$ diameter mesh sieve. Upon drying under ambient conditions for 3 hours, the granules were filled into size 3 capsules as previously described. To prepare 40 capsules, 
$6.4 \mathrm{~g}$ of granules were needed, i.e. $160 \mathrm{mg}$ of granules were needed to fill one capsule, according to the granules' density and the capsule volume.

3. Preparation of mini tablets

The tablet mixture was prepared by mixing appropriate amounts of tablet ingredients in a mortar with a pestle for 10 minutes. PROP $3 \mathrm{mg}$ mini tablets were prepared with PROP $(23 \% \mathrm{w} / \mathrm{w})$, Parteck ${ }^{\circledR}$ M $200(75 \% \mathrm{w} / \mathrm{w})$ and magnesium stearate $(2 \% \mathrm{w} / \mathrm{w})$, adjusting the average weight of the mini tablet to $13 \mathrm{mg}$. Similarly, PROP $6 \mathrm{mg}$ mini tablets were prepared with PROP (37.5\% w/w), Parteck ${ }^{\circledR}$ M $200(60.5 \% \mathrm{w} / \mathrm{w})$ and magnesium stearate $(2 \% \mathrm{w} / \mathrm{w})$, where the average mini tablet weight was $16 \mathrm{mg}$. Mini tablets were made by the direct compression method on a compaction analyzer Gamlen D-series (Gamlen Tableting, UK) using a punch and a die with $3 \mathrm{~mm}$ diameter. Compression was performed with a compression force of $1175 \mathrm{~N}$.

4. Flow properties of prepared powders and granules

Flow properties of the prepared powders and granules were tested using both direct and indirect methods. The direct method is based on measuring the time required for the precise amount of powders/granules sample to pass through the orifice of the flow tester (Erweka flow meter GDT, Erweka GmbH, Germany). The test was performed in triplicate for each sample. The indirect method refers to the calculation of the Hausner ratio (HR) and Compressibility index (Carr index, $C I$ ), based on the measured bulk and tapped sample volumes, as according to the following equations (25). The bulk density was determined in a graduated $50 \mathrm{~mL}$ cylinder. $10 \mathrm{~g}$ of powder/granule sample was measured and poured into the cylinder. The bulk density was calculated as the ratio of powder/granule mass and read volume. The tapped density was determined by the mechanical tapping of the graduated cylinder containing $10 \mathrm{~g}$ sample of powder/granule using STAV 2003 tap density tester (J. Engelsmann, Germany). The number of taps was 1250. The tapped density was calculated as the ratio of powder/granule mass and the final tapped volume.

$$
\begin{aligned}
& C I=\frac{\rho_{\text {tapped }-\rho \text { bulk }}}{\rho_{\text {tapped }}} \times 100 \\
& H R=\frac{\rho_{\text {tapped }}}{\rho_{\text {bulk }}}
\end{aligned}
$$

In accordance with the calculated $C I$ and $H R$ values, powder/granule flow was characterized according to the flowability scale (Ph. Eur. 10.0, 2.9.36.) (Table II). 
Table II Flowability scale (25)

Tabela II Skala protočnosti (25)

\begin{tabular}{ccc}
\hline Carr index (\%) & Flow character & Hausner ratio \\
\hline $1-10$ & excellent & $1.00-1.11$ \\
\hline $11-15$ & good & $1.12-1.18$ \\
\hline $16-20$ & fair & $1.19-1.25$ \\
\hline $21-25$ & passable & $1.26-1.34$ \\
\hline $26-31$ & poor & $1.35-1.45$ \\
\hline $32-37$ & very poor & $1.46-1.59$ \\
\hline$>38$ & very, very poor & $>1.60$ \\
\hline
\end{tabular}

5. Uniformity of mass of the prepared mini tablets and capsules

The test was performed on 20 randomly selected mini tablets or capsules. Each tablet was accurately weighed using a BP201 D analytical balance (Sartorius AG, Germany). The average tablet mass and standard deviation (SD) from the average tablet mass were calculated for each sample. The uniformity of mass test for capsules was performed by measuring the difference between the mass of the intact capsule and the capsule shell.

For both mini tablets and capsules, the compendial requirements were met if maximum two individual masses deviated by more than $10 \%$, but no single individual mass deviated by more than $20 \%$ of the average mass (25).

6. Content uniformity of PROP in the prepared mini tablets and capsules

The test was performed by determining individual PROP content in 10 randomly taken mini tablets and capsules, and by calculating the average content. Each sample (i.e., crushed tablet or content of a capsule) was transferred to a $25 \mathrm{ml}$ volumetric flask. Then, $1 \mathrm{ml}$ of dilute hydrochloric acid $(1 \% \mathrm{~V} / \mathrm{V})$ was added and filled with methanol up to $2 / 3$ of the flask volume and sonicated for 10 minutes on an ultrasonic bath (Bandelin Sonorex RK102H, Germany). After that, the volumetric flask was filled to the mark with methanol. PROP content was determined UV spectrophotometrically at the wavelength of maximum absorption $(290 \mathrm{~nm})$. The tablets and capsules comply with the test if not more than one individual content was outside the limits of $85 \%$ to $115 \%$ of the average content and if no individual content was outside the limits of $75 \%$ to $125 \%$ of the average content (25). 


\section{Results and discussion}

According to the available data on the use of drugs for pediatric treatment in the local community, PROP is one of the ten most frequently prescribed drugs, where almost one-half of the total number of prescriptions were for cardiovascular drugs (26). The data also show that this drug is often prescribed in an off-label manner (in terms of the dose). Another issue concerning this drug is related to the unavailability of a suitable ageappropriate dosage form and dose for pediatric patients. To exemplify this, the only available PROP product on the local market (uncoated tablets) is available in a single strength of $40 \mathrm{mg}$, although the SmPC states the tablets can be administered to pediatric patients in smaller, adjusted doses. For this purpose, it is recommended to split the tablet into up to four pieces (the tablets are scored with cross-lines to facilitate breaking, Figure $3 \mathrm{~A})$.

This procedure is related to two additional issues: firstly, the splitting of the tablet can only provide a single dose of 10-30 mg, which does not comply with the recommended dose adjustments based on a child's body weight; secondly, it is questionable whether tablet splitting ensures uniform and appropriate dosing.

In order to investigate the latter issue, we have tested the suitability of scored PROP tablets for splitting using five different splitting techniques. The results for the uniformity of mass of the subdivided parts are shown in Table III and Figure 4.

The obtained results demonstrate that the pharmacopoeial requirements have been met solely for half-tablets obtained by techniques 4 and 5 . However, the results for the splitting technique 5 should be taken with caution due to the visible loss of mass during tablet splitting (Figure 4B). Namely, Ph. Eur. 10.0 suggests that only one part from each tablet should be taken for the test (while rejecting the residual parts and "lost" fragments), and therefore compliance of the mass of the selected part with the required limits may represent false-positive results. Currently, there are no pharmacopoeial requirements for the maximum loss of mass upon tablet splitting, but this issue should be reconsidered in the future. Splitting techniques 1-3 resulted in higher variations between the tablet halves because the tablets often broke apart from the score line (Figure 4C). However, the most important finding is that none of the applied splitting techniques gave quarter-tablets of the appropriate mass (Table III). Regardless of the splitting technique, most of the tablets broke apart from the score lines, the obtained tablet quarters differed in mass, there were considerable mass losses, and some quarters even crumbled into multiple pieces (Figure 3D). Although the product's SmPC states that the tablets can be divided into four equal parts, the presented results clearly demonstrate that this statement is highly questionable. In addition, it was previously demonstrated (1) that active pharmaceutical ingredients may not be uniformly distributed within the dosage form, such as a tablet, which may potentially cause a non-uniform dose in the crushed tablet fragments. Therefore, additional options, besides the subdivision of tablets, should be considered to provide pediatric patients with the appropriate PROP dose. In this context, the crushing of tablets and concomitant compounding of a suitable dosage form i.e., multiparticulate system may serve as a better alternative. 

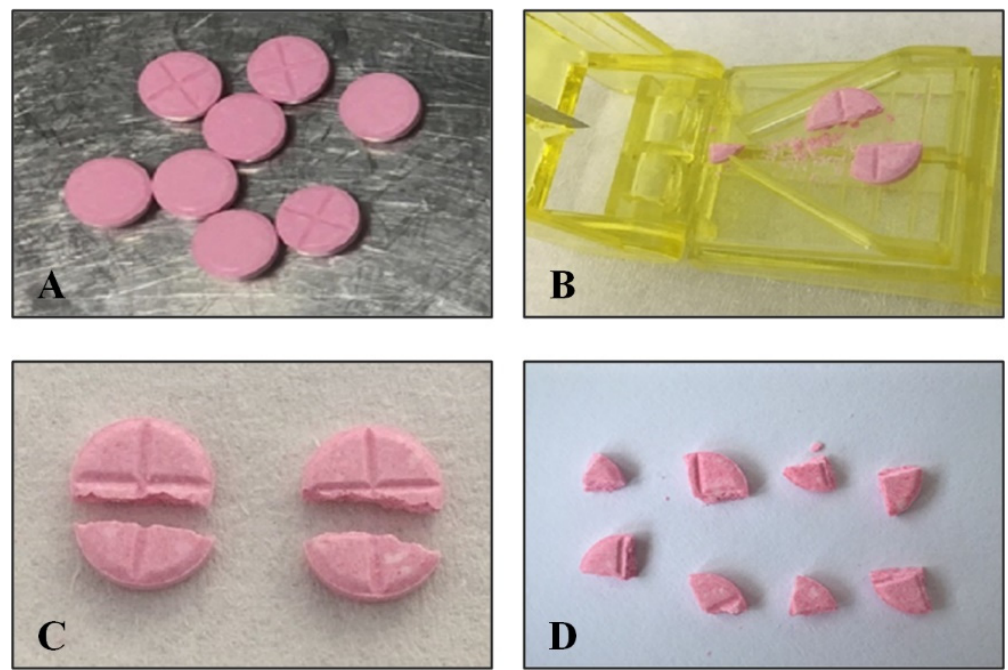

Figure 3. (A) The appearance of Propranolol ${ }^{\circledR} 40 \mathrm{mg}$ scored tablets (Galenika AD, Serbia); (B) Loss of mass after using a tablet-splitter; (C) Examples of unequal half-tablets and (D) Examples of unequal quarter-tablets.

Slika 3. (A) Izgled Propranolol ${ }^{\circledR} 40$ mg tableta (Galenika AD, Srbija); (B) Gubitak mase prilikom deljenja tableta pomoću "sekača"; (C) Primeri nejednakih polovina tableta i (D) Primeri nejednakih četvrtina tableta

Table III The results of the tablets subdivision test

Tabela III Rezultati ispitivanja deljivosti tableta

\begin{tabular}{|c|c|c|c|c|c|c|}
\hline \multirow{2}{*}{\multicolumn{3}{|c|}{ Sample tested }} & \multirow{2}{*}{$\begin{array}{l}\text { Average mass and } \\
\text { standard deviation } \\
(\mathrm{g})\end{array}$} & \multicolumn{2}{|c|}{$\begin{array}{c}\text { Number of tablets outside the } \\
\text { limits }\end{array}$} & \multirow{2}{*}{$\begin{array}{l}\text { Compliance } \\
\text { with } \\
\text { Ph. Eur. } 10\end{array}$} \\
\hline & & & & $\begin{array}{l}85-115 \% \text { of the } \\
\text { average mass }\end{array}$ & $\begin{array}{c}75-125 \% \text { of } \\
\text { the average } \\
\text { mass }\end{array}$ & \\
\hline \multicolumn{3}{|c|}{ PROP commercial tablets } & $0.2017 \pm 0.0019$ & - & - & + \\
\hline \multirow{10}{*}{ 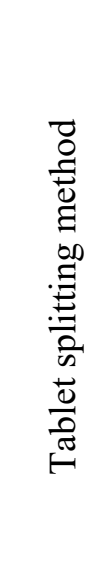 } & \multirow{2}{*}{1} & HT & $0.1020 \pm 0.0134$ & 7 & - & - \\
\hline & & QT & $0.0499 \pm 0.0100$ & 8 & 6 & - \\
\hline & \multirow{2}{*}{2} & HT & $0.1026 \pm 0.0115$ & 2 & 1 & - \\
\hline & & QT & $0.0534 \pm 0.0100$ & 9 & 4 & - \\
\hline & \multirow{2}{*}{3} & HT & $0.1050 \pm 0.0221$ & 16 & 6 & - \\
\hline & & QT & $0.0565 \pm 0.0129$ & 14 & 8 & - \\
\hline & \multirow{2}{*}{4} & HT & $0.1020 \pm 0.0088$ & 1 & - & + \\
\hline & & QT & $0.0528 \pm 0.0056$ & 3 & - & - \\
\hline & \multirow{2}{*}{5} & HT & $0.0950 \pm 0.0078$ & - & - & + \\
\hline & & QT & $0.0444 \pm 0.0060$ & 5 & 2 & - \\
\hline
\end{tabular}

HT - half tablet, QT - quarter tablet 
A

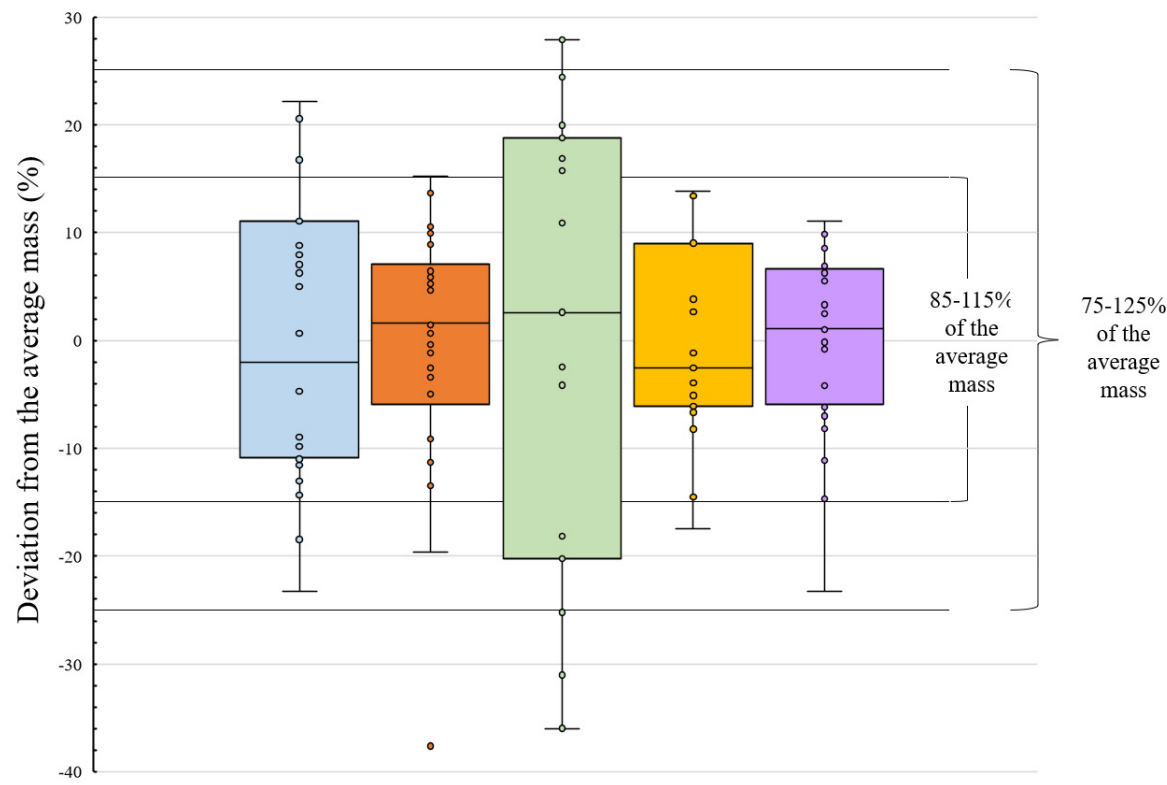

B

$\square 1 \square 2 \square 3 \square 4 \square 5$

The technique used to split tablets in half

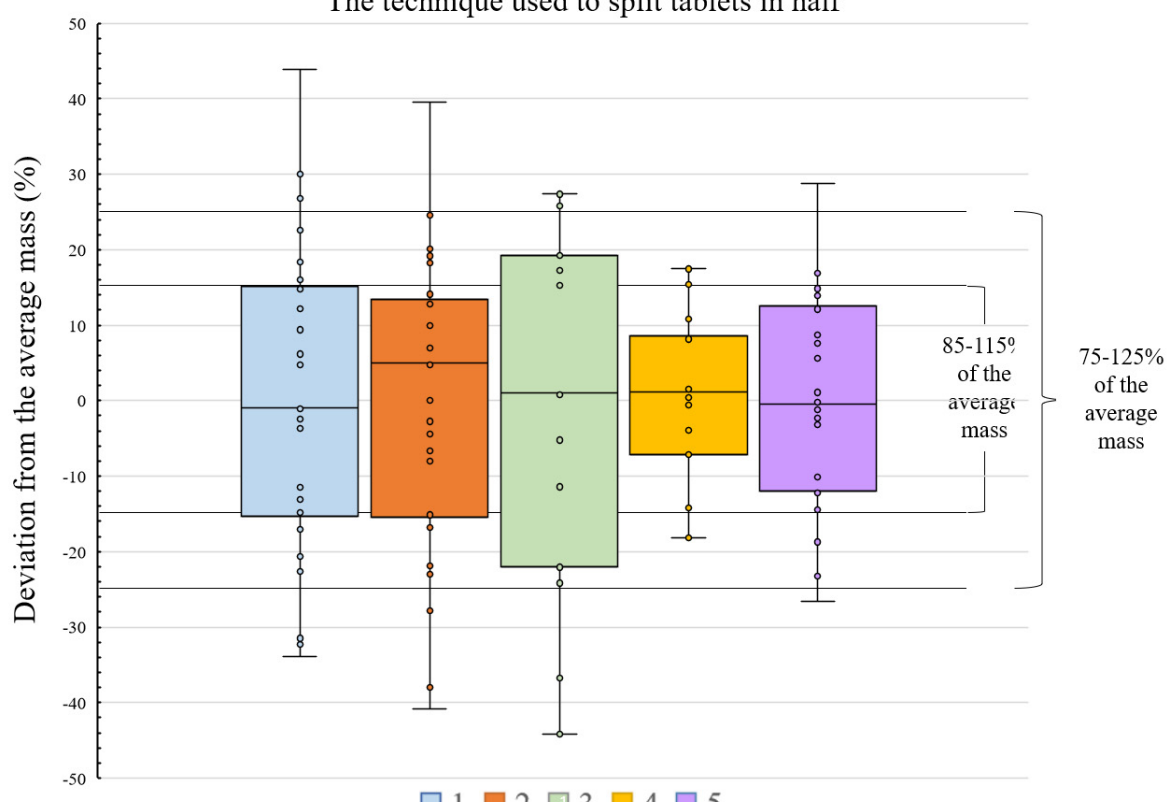

$\square 1 \square 2 \square 3 \square 4 \square 5$

The technique used to split tablets in quarter

Figure 4. Uniformity of mass results of tablets split in (A) half or (B) quarter Slika 4. Rezultati ispitivanja variranja mase tableta podeljenih na (A) polovine ili (B) četvrtine 
In addition, the compounding of other multiparticulate formulations should be evaluated. PROP granule-filled capsules and mini tablets prepared in this study are represented in Figure 5. Extemporaneous compounding of pediatric formulations can be quite useful, especially when the appropriate strength of a licensed medicine or adequate dosage form is not available, when the active substance or commercial preparation has unacceptable organoleptic properties (e.g., unpleasant taste or smell), or in cases of drug shortages (e.g., the medicine is not available from the supplier). However, this approach is associated with certain risks, and it is up to the pharmacist to prepare an age-appropriate medicine of appropriate quality, safety, stability, and efficacy.

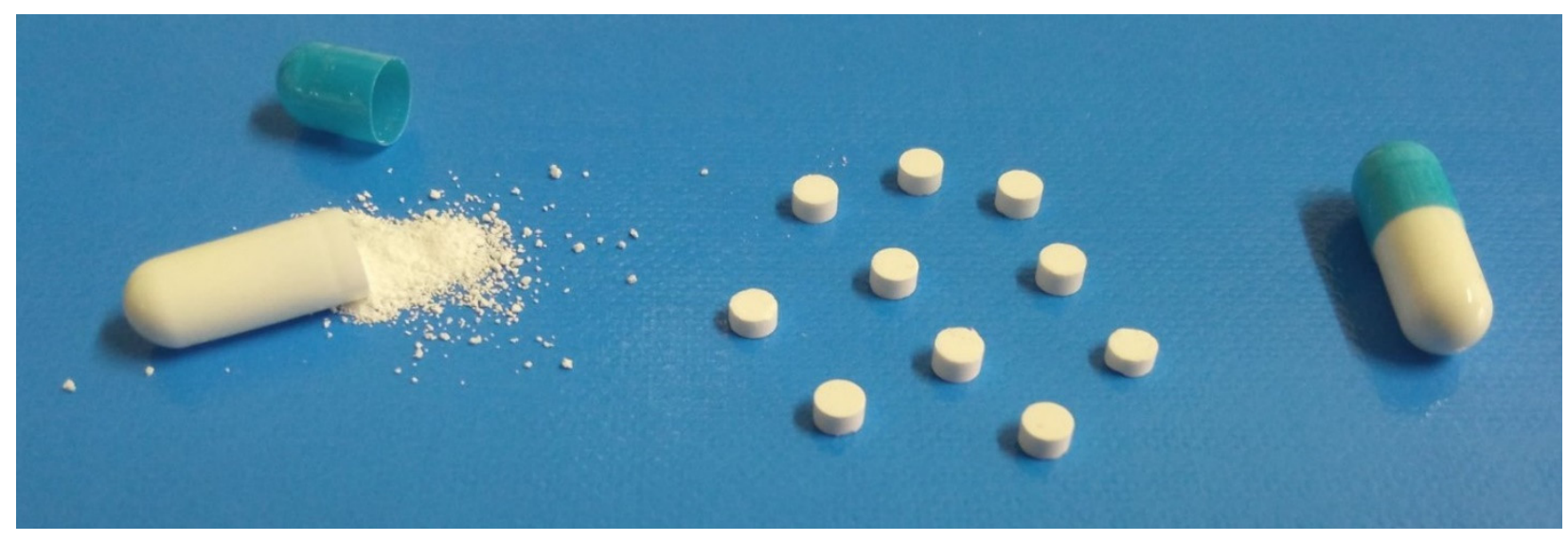

Figure 5. The appearance of the compounded PROP multiparticulate oral fomulations: granule-filled capsules and mini tablets

Slika 5. Izgled izrađenih višečestičnih formulacija propranolola za oralnu primenu: kapsule punjene granulama i mini tablete

Once the powder- and granule-filled capsules were prepared, they were tested for mass and content uniformity. In addition, both powder and granules' flowability was analyzed. Results of the mass and content uniformity for PROP capsules (powder- and granule-filled) are represented in Table IV and Figure 6 . The obtained results indicate that $6 \mathrm{mg}$ PROP granule-filled capsules met Ph. Eur. 10.0 requirements, since the individual mass of all 20 tested capsules fell within the allowed interval of $\pm 10 \%$ of the average content mass. In the case of $6 \mathrm{mg}$ PROP powder-filled capsules, the contents of 3 capsules varied by more than $10 \%$ of the average but were within $\pm 20 \%$ of the average content mass. The obtained results for the content uniformity revealed that both in the case of 3 $\mathrm{mg}$ and $6 \mathrm{mg}$ PROP powder-filled capsules content of 2 capsules deviated from the $\pm 15 \%$ tolerance limit. In the case of $3 \mathrm{mg}$ PROP powder-filled capsules, one content varied more than $\pm 25 \%$. In that sense, $3 \mathrm{mg}$ and $6 \mathrm{mg}$ PROP powder-filled capsules failed to meet the compendial requirements regarding the uniformity of the content and mass variation, respectively. 
Table IV The results of mass variation and content uniformity test for powder-filled capsules, granule-filled capsules and mini tablets

Tabela IV Rezultati ispitivanja variranja mase i ujednačenosti sadržaja za kapsule punjene praškom, kapsule punjene granulama i mini tablete

\begin{tabular}{|c|c|c|c|c|c|c|}
\hline \multirow{2}{*}{\multicolumn{2}{|c|}{ Sample tested }} & \multirow[t]{2}{*}{$\begin{array}{l}\text { Average mass and } \\
\text { standard deviation } \\
\text { (g) }\end{array}$} & \multicolumn{2}{|c|}{$\begin{array}{l}\text { Number of } \\
\text { tablets/capsules outside } \\
\text { the limits of the average } \\
\text { mass }\end{array}$} & \multicolumn{2}{|c|}{$\begin{array}{l}\text { Number of tablets/capsules } \\
\text { with PROP content outside } \\
\text { the limits of the average } \\
\text { PROP content }\end{array}$} \\
\hline & & & $90-110 \%$ & $80-120 \%$ & $85-115 \%$ & $75-125 \%$ \\
\hline \multirow{2}{*}{ 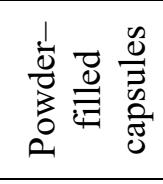 } & $\begin{array}{l}3 \mathrm{mg} \\
\text { PROP }\end{array}$ & $0.2938 \pm 0.0080$ & - & - & 2 & 1 \\
\hline & $\begin{array}{l}6 \mathrm{mg} \\
\text { PROP }\end{array}$ & $0.2142 \pm 0.0146$ & 3 & - & 2 & - \\
\hline \multirow{2}{*}{ 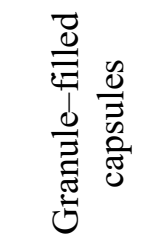 } & $\begin{array}{l}3 \mathrm{mg} \\
\text { PROP }\end{array}$ & $0.1955 \pm 0.0053$ & - & - & - & - \\
\hline & $\begin{array}{l}6 \mathrm{mg} \\
\text { PROP }\end{array}$ & $0.1954 \pm 0.0053$ & - & - & - & - \\
\hline \multirow{2}{*}{$\begin{array}{l}\frac{\mathscr{n}}{0} \\
\frac{\pi}{ \pm} \\
\vdots \\
\sum\end{array}$} & $\begin{array}{l}3 \mathrm{mg} \\
\text { PROP }\end{array}$ & $0.0129 \pm 0.0004$ & - & - & 1 & - \\
\hline & $\begin{array}{l}6 \mathrm{mg} \\
\text { PROP }\end{array}$ & $0.0156 \pm 0.0004$ & - & - & 2 & - \\
\hline
\end{tabular}

On the other hand, PROP content in all of the 10 tested granule-filled capsules of both strengths was within the $\pm 15 \%$ interval of the average content variation tolerated by $\mathrm{Ph}$. Eur. 10. Therefore, in the case of granule-filled capsules, both $3 \mathrm{mg}$ and $6 \mathrm{mg}$ PROP containing samples met the compendial requirements regarding mass variation and content uniformity. 
A

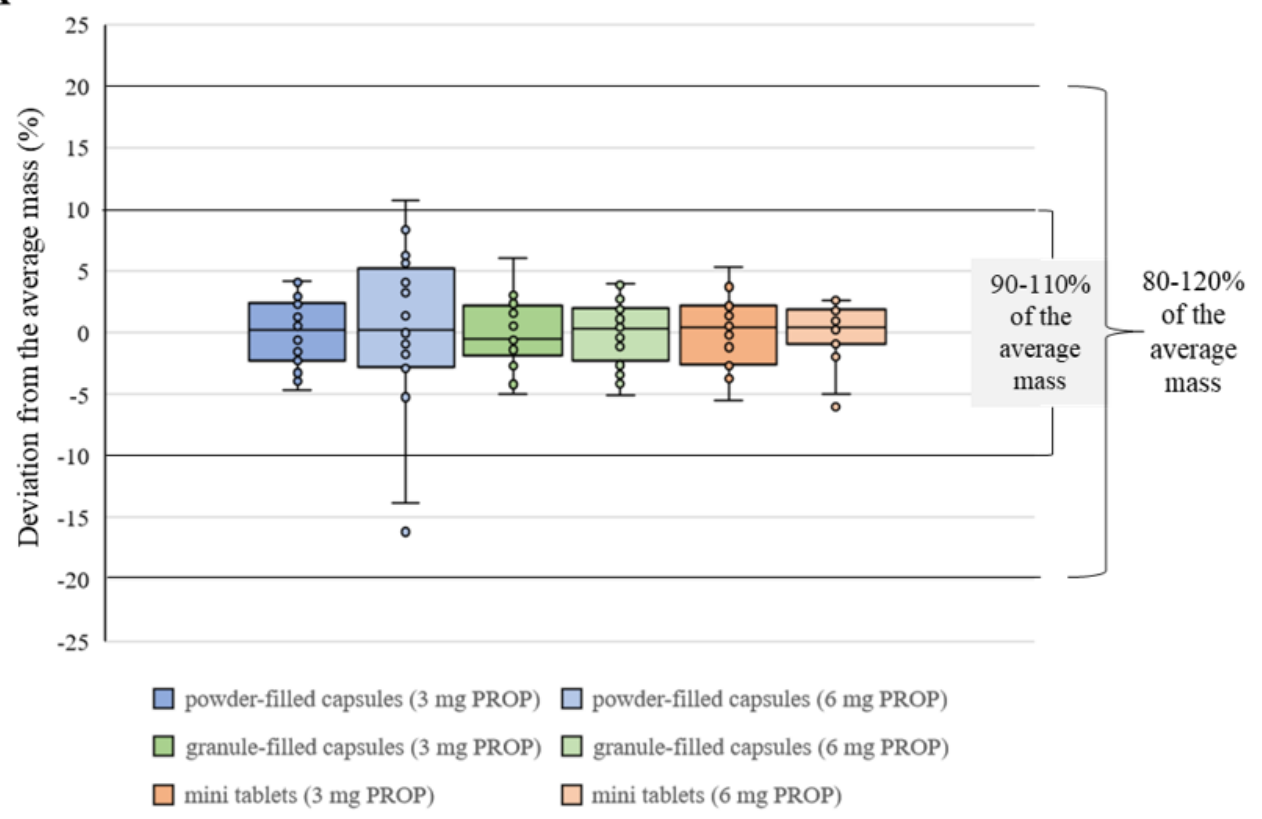

B

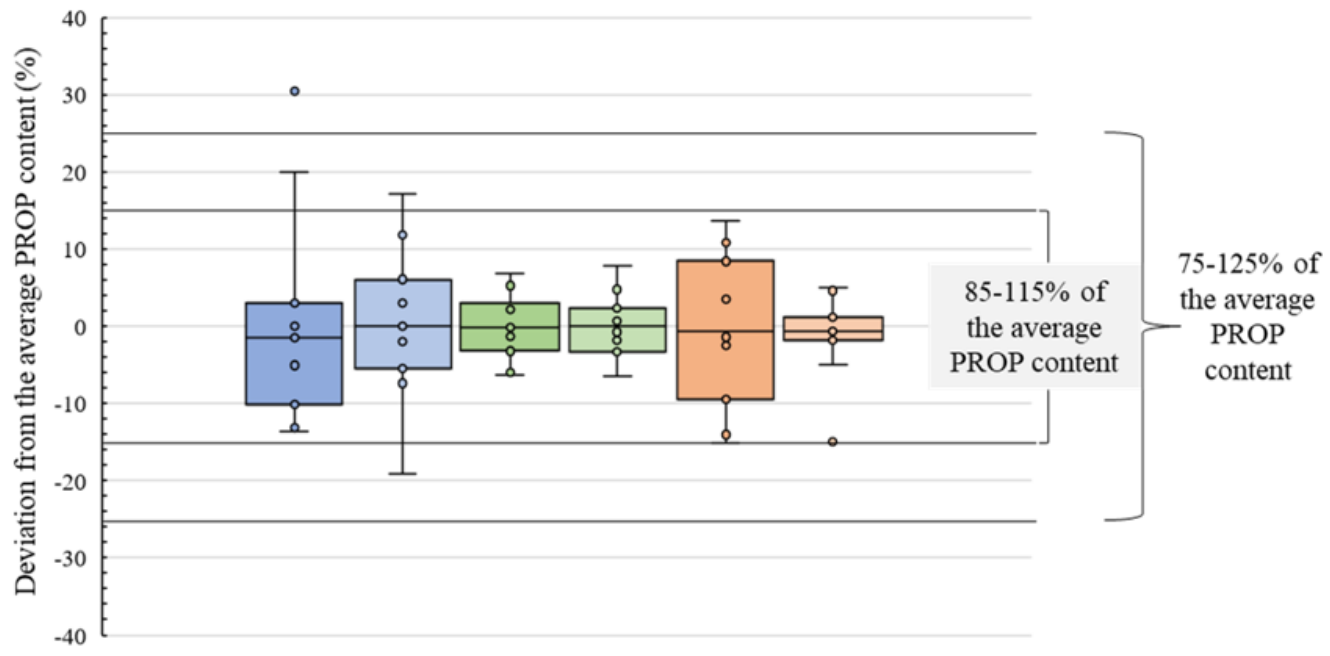

$\square$ powder-filled capsules (3 mg PROP) $\square$ powder-filled capsules (6 mg PROP)

$\square$ granule-filled capsules (3 mg PROP) $\square$ granule-filled capsules (6 mg PROP)

$\square$ mini tablets (3 mg PROP) $\quad \square$ mini tablets (6 mg PROP)

Figure 6. (A) Uniformity of mass results for PROP $3 \mathrm{mg}$ and $6 \mathrm{mg}$ powder-filled capsules, granule-filled capsules, and mini tablets; (B) Results of the test for uniformity of content for PROP $3 \mathrm{mg}$ and $6 \mathrm{mg}$ powder-filled capsules, granule-filled capsules, and mini tablets

Slika 6. (A) Rezultati ispitivanja variranja mase za kapsule punjene praškom ili granulama i mini tablete koje sadrže 3 mg ili 6 mg PROP; (B) Rezultati određivanja ujednačenosti sadržaja za kapsule punjene praškom ili granulama i mini tablete koje sadrže 3 mg ili 6 mg PROP 
It can be assumed that differences in the powders and granules flowability may affect the uniformity of capsule filling. For that matter, the flow properties of samples were analyzed. The direct method for flowability determination indicated notable differences between powder and granules. Namely, the average flow rates were $4.85 \mathrm{~g} / \mathrm{s}$ and $8.08 \mathrm{~g} / \mathrm{s}$ for powder and granules, respectively. Almost double the amount of granules flows through the orifice of the flow tester at the same time compared to the powder, implying much better flow properties of granules. The results of the indirect flowability testing method confirm the assumption: the calculated $C I$ and $H R$ values for the powder $(C I=12.12 \%$ and $H R=1.14)$ characterized powder flow as "good", whereas the granules flow properties were characterized as "excellent" $(C I=6.9 \%$ and $H R=1.07)$. Here, we need to point out that the use of Parteck ${ }^{\circledR}$, an excipient with excellent flow properties (27) as a filler contributed to the overall flow characteristics of the prepared powder and granules. However, the granulation of powders, due to an increase in particle size, further improved their flow properties, and consequently, the uniformity of content of the prepared granules-filled capsules. It must be highlighted that improved flow properties are relevant not only for the time consumption for the overall capsule filling procedure, but also for the uniform flow that provides the uniform filling of capsules. Furthermore, the handling of granules during capsule-filling is much more convenient, compared to powders, in terms of potential dusting, spilling, etc.

Regarding the properties of mini tablets, both $3 \mathrm{mg}$ and $6 \mathrm{mg}$ PROP mini tablets met the compendial requirements in terms of uniformity of mini tablets mass and PROP content (Table IV and Figure 6). It needs to be noted that due to the usage of directly compressible filler, it was possible to incorporate relatively high amounts of PROP in mini tablets $(37.5 \% \mathrm{w} / \mathrm{w}$ for $6 \mathrm{mg}$ PROP mini tablets). In that sense, PROP mini tablets provide the means for convenient and flexible adjustment of PROP doses. In practice, PROP mini tablets of different strengths could be combined to achieve the appropriate dosage. In terms of comparison of the variation of PROP content in different multiparticulate systems, the smallest variation was observed for granule-filled capsules, followed by mini tablets and then by the powder-filled capsules. Compared to the conventional tablets split into halves and quarters, multiparticulate oral formulations have been demonstrated to have significantly improved PROP content uniformity.

\section{Conclusion}

The study presented an investigation of the feasibility of appropriate PROP dose adjustment and uniform dosing, which is relevant for its administration to pediatric patients, by using different methods: the splitting of the conventional tablets and compounding of multiparticulate oral formulations- powder- and granule-filled capsules, as well as mini tablets. The obtained results are indicative of the superiority of multiparticulates for the test of uniformity of content for PROP. These findings support contemporary recommendations for the development of specific dosage forms for pediatric patients and are especially relevant due to the possibility of the application of the presented compounding methods in community pharmacy settings. Furthermore, the 
study supports further development of mini tablets as a convenient dosage form for flexible dose adjustment.

\section{Acknowledgment}

This study has been supported by the Ministry of Education, Science and Technological Development of the Republic of Serbia, contract number 451-03-68/202014/200161. The preparation of mini tablets was performed by Ivana Kurćubić during her research visit at the Department of Pharmaceutical Technology, Medical University of Gdansk, supported by the CEEPUS network CIII-RS-1113-00-1718. The authors would also like to thank students Dajana Timar and Mitar Lalić for their help in experimental work.

\section{Reference}

1. Zajicek A, Fossler MJ, Barrett JS, Worthington JH, Ternik R, Charkoftaki G, et al. A report from the pediatric formulations task force: perspectives on the state of child-friendly oral dosage forms. AAPS J. 2013;15(4):1072-81.

2. Thabet Y, Klingmann V, Breitkreutz J. Drug formulations: Standards and novel strategies for drug administration in pediatrics. J Clin Pharmacol. 2018;58(S10):S26-S35.

3. Trofimiuk M, Wasilewska K, Winnicka K. How to modify drug release in paediatric dosage forms? Novel technologies and modern approaches with regard to children's population. Int J Mol Sci. 2019;20(13):3200.

4. Galande AD, Khurana NA, Mutalik S. Pediatric dosage forms-challenges and recent developments: A critical review. J Appl Pharm Sci. 2020;10(07):155-66.

5. European Medicines Agency: EMA/CHMP/QWP/805880/2012 - Guideline on pharmaceutical development of medicines for paediatric use 2013 [Internet] [Cited 2020 April]. Available from: https://www.ema.europa.eu/en/documents/scientific-guideline/guidelinepharmaceuticaldevelopment-medicines-paediatric-use_en.pdf.

6. World Health Organization: QAS/08.257/Rev.3. Geneva, 2011. Annex 5: Development of paediatric medicines: points to consider in formulation [Internet] [Cited 2020 April]. Available from: https://www.who.int/medicines/areas/quality_safety/quality_assurance/Annex5TRS970.pdf?ua=1.

7. European Medicines Agency: EMEA/CHMP/PEG/194810/2005 - Reflection paper: Formulations of choice for the paediatric population 2006 [Internet] [Cited 2020 April]. Available from: https://www.ema.europa.eu/en/documents/scientific-guideline/reflection-paper-formulationschoice-paediatric-population_en.pdf. 
8. European Medicines Agency: EMA/761434/2010 - Report on the survey of all paediatric uses of medicinal products in Europe: Executive summary 2011 [Internet] [Cited 2020 April]. Available from:https://www.ema.europa.eu/en/documents/other/report-survey-all-paediatric-usesmedicinalproducts-europe-executive-summary_en.pdf.

9. Medicines.org.uk. 2020. Propranolol tablets $10 \mathrm{mg}$ BP - Summary of Product Characteristics (SPC) - (Emc) [Internet] [Cited 2020 May 24]. Available from: https://www.medicines.org.uk/emc/product/5888/smpc.

10. Alims.gov.rs 2020. Propranolol tablets $40 \mathrm{mg}$ - Summary of Product Characteristics (SPC) Medicines and Medical Devices Agency of the Republic of Serbia [Internet] [Cited 2020 July 24]. Available from: https://www.alims.gov.rs/ciril/files/lekovi/smpc/515-01-01419-17-001.pdf.

11. European Medicines Agency. Hemangiol $3.75 \mathrm{mg} / \mathrm{ml}$ oral solution - Summary of Product Characteristics (SPC). [Internet] [Cited 2020 May 24]. Available from:

https://www.ema.europa.eu/en/documents/product-information/hemangioleparproductinformation_en.pdf

12. Van Vooren L, De Spiegeleer B, Thonissen T, Joye P, Van Durme J, Slegers G. Statistical analysis of tablet breakability methods. J Pharm Pharmaceutic Sci. 2002;5(2):190-8.

13. Van Santen E, Barends DM, Frijlink HW. Breaking of scored tablets: a review. Eur J Pharm Biopharm. 2002;53(2):139-45.

14. Hill SW, Varker AS, Karlage K, Myrdal PB. Analysis of drug content and weight uniformity for half-tablets of 6 commonly split medications. J Manag Care Pharm. 2009;15(3):253-61.

15. Teng J, Song CK, Williams RL, Polli JE. Lack of medication dose uniformity in commonly split tablets. J Am Pharm Assoc (Wash). 2002;42(2):195-9.

16. Ranmal SR, Cram A, Tuleu C. Age-appropriate and acceptable paediatric dosage forms: Insights into end-user perceptions, preferences and practices from the Children's Acceptability of Oral Formulations (CALF) Study. Int J Pharm. 2016;514(1):296-307.

17. Lee HS, Lee JJ, Kim MG, Kim KT, Cho CW, Kim DD, Lee JY. Sprinkle formulations - A review of commercially available product. Asian J Pharm Sci. 2020;15(3):292-310.

18. Stoltenberg I, Breitkreutz J. Orally disintegrating mini-tablets (ODMTs) - A novel solid oral dosage form for paediatric use. Eur J Pharm Biopharm. 2011;78(3):462-9.

19. Thomson SA, Tuleu C, Wong ICK, Keady S, Pitt KG, Sutcliffe AG. Minitablets: New modality to deliver medicines to preschool-aged children. Pediatrics. 2009;123(2):235-8.

20. Wening K, Breitkreutz J. Oral drug delivery in personalized medicine: Unmet needs and novel approaches. Int J Pharm. 2011;404(1-2):1-9.

21. Iyire A, Mohammed AR. Multiparticulate systems for paediatric drug delivery. In: Rajabi-Siahboomi AR. Multiparticulate Drug Delivery. New York: Springer; 2017; p. 213-36.

22. Desitin.de/produkte/orfiril-long/2020. Orfiril long $150 \mathrm{mg}$ - Patient information leaflets (PIL) [Internet] Desitin Arzneimittel GmbH [Cited 2020 July 26]. Available https://www.desitin.de/wpcontent/uploads/2019/08/Orfiril_long_150mg-300mg_GI.pdf.

23. Desitin.de/produkte/levetiracetam-desitin/ 2020. Levetiracetam DESITIN $250 \mathrm{mg}$ - Patient information leaflets (PIL) [Internet] Desitin Arzneimittel GmbH [Cited 2020 July 26]. Available from: https://www.desitin.de/wpcontent/uploads/2019/09/Levetiracetam_Desitin_GI.pdf. 
24. Enzym Lefax forte kapseln [Internet] [Cited 2020 July 26]. Available from:

https://www.medikamente-per-klick.de/images/ecommerce/02/56/02563871_2008

25. 06_de_o.pdf.

26. European Pharmacopoeia (Ph. Eur.). 10th ed, Strasbourg: Council of Europe, 2020.

27. Bajcetic M, Jelisavcic M, Mitrovic J, Divac N, Simeunovic S, Samardzic R, Gorodischer R. Off label and unlicensed drugs use in paediatric cardiology. Eur J Clin Pharmacol. 2005;6:775-9.

28. Paul S, Chang SY, Dun J, Sun WJ; Wang K, Tajarobi P, et al. Comparative analyses of flow and compaction properties of diverse mannitol and lactose grades. Int J Pharm. 2018;546(1-2):39-49. 


\title{
Višečestične formulacije lekova za oralnu primenu kao strategija za precizno doziranje kod pedijatrijskih pacijenata: studija slučaja propranolola
}

\author{
Ivana Kurćubić ${ }^{1 *}$, Sandra Cvijićc ${ }^{1}$, Milica Lukić \\ Svetlana Ibrić ${ }^{1}$, Jelena Djuriś ${ }^{1}$ \\ ${ }^{1}$ Univerzitet u Beogradu - Farmaceutski fakultet, Katedra za farmaceutsku tehnologiju i \\ kozmetologiju, Vojvode Stepe 450, 11221 Beograd, Srbija \\ ${ }^{2}$ Apotekarska ustanova "Dr.Max", Miloša Pocerca 25, 11000, Beograd, Srbija \\ * Autor za korespodenciju: Ivana Kurćubić, E-mail: ivana.kurcubic@pharmacy.bg.ac.rs
}

\section{Kratak sadržaj}

Razvoj čvrstih farmaceutskih oblika lekova koji su prikladni za primenu kod pedijatrijske populacije pacijenata, ali koji istovremeno omogućavaju i precizno doziranje lekovite supstance, predstavlja jedan od vodećih izazova u farmaceutskoj tehnologiji. Prikazana studija koristi propranolol-hidrohlorid, kao jedan od najčešće primenjivanih lekova koji zahteva prilagođavanje farmaceutskih oblika za primenu kod dece. Višečestični farmaceutski oblici u vidu kapsula napunjenih praškom ili granulama, kao i mini tablete, su izrađene $\mathrm{i}$ ispitane u pogledu variranja mase i ujednačenosti sadržaja lekovite supstance. Dobijeni rezultati su upoređeni sa variranjem mase uzoraka koji se dobijaju deljenjem konvencionalnih registrovanih tableta na polovine i četvrtine. Dobijeni rezultati ukazuju na superiornost višečestičnih farmaceutskih oblika, zbog visokog stepena ujednačenosti mase i sadržaja lekovite supstance. Takođe je pokazano da se, zbog unapređene protočnosti, kapsule lakše pune granulama u odnosu na praškove, kao i da takvi farmaceutski oblici imaju veću ujednačenost mase i sadržaja lekovite supstance. Predstavljeni postupak izrade je jednostavan za izvođenje u uslovima apoteke. Mini tablete sa visokim udelom i ujednačenim sadržajem propranolol-hidrohlorida su uspešno izrađene, i predstavljaju značajnu strategiju koja može da omogući efikasno prilagođavanje doze lekovite supstance.

Ključne reči: propranolol, pedijatrijski farmaceutski oblici, višečestični sistemi, mini tablete, ujednačenost sadržaja 